\title{
Guarantee Of Worker Rights During The Covid 19 Pandemic
}

\author{
Rosalia Dika Agustanti ${ }^{1}$ \\ Yuliana Yuli W ${ }^{2}$ \\ Satino $^{3}$ \\ ${ }^{1}$ Faculty of Law, Universitas Pembangunan Nasional Veteran Jakarta, Indonesia. E-mail: rosaliadika@upnvj.ac.id \\ 2 Faculty of Law, Universitas Pembangunan Nasional Veteran Jakarta, Indonesia. E-mail: yulianayuli@upnvj.ac.id \\ ${ }^{3}$ Faculty of Law, Universitas Pembangunan Nasional Veteran Jakarta, Indonesia. E-mail: satino@upnvj.ac.id
}

\section{Article Info}

Keywords:

Worker Rights; Labor:

COVID-19; Companies.

How to cite (APA Citation

Style):

Agustanti, R.D, et al. (2020). "Guarantee of Worker Rights During The Covid 19 Pandemic". Jambura Law Review. JALREV 3 Special Issue: 77-95

\begin{abstract}
This research discusses the rights of workers / laborers during the COVID-19 pandemic and what if the employers do not meet these rights. Problem which is more in-depth about the employment that emerged during this pandemic, namely the occurrence of massive layoffs. The research was conducted using the Normative Juridical method. By applying the Statute Approach, Conceptual Approach, and Case Approach, the results show that employers have not been able to fulfill workers / labor rights during the COVID-19 pandemic. There are companies that have not implemented the clean lifestyle and occupational health standards K3 protection such as masks, hand sanitizer and personal protective equipment. Prevention and handling policies are still not optimal, the principle of maintaining social distancing has not been implemented optimally, there are still many workers who are jostling for work when they come to work, not to mention during the trip to work in public transportation. This situation makes them vulnerable to infection. However, they still have to go to work because of the risk of losing their income. Efforts that can be made if wages are not paid are to take the route or methods as regulated in Law Number 2 of 2004 concerning Settlement of Industrial Relations Disputes. The basis of a dispute between a worker/ laborer and an entrepreneur is a dispute over rights.
\end{abstract}




\section{Introduction}

Coronavirus Disease 2019 (COVID-19) was discovered at the end of 2019 to be precise in December in Wuhan City, Huebei Province, China and then spread to almost all over the world. Covid-19 is caused by a new type of betacoronavirus which tends to resemble SARS-CoV and MERS-CoV. ${ }^{4}$ Amnesty International Indonesia together with the Center for Labor Studies and Advocacy, Trade Unions Rights Center (TURC), urge the government to ensure protection of the security, safety and welfare of workers from all sectors, especially vulnerable groups and informal workers, during the response to the COVID-19 corona virus outbreak. Slowly but surely, the company's production chain activities will stop, people's income will decrease and even disappear and national consumption will be disrupted.

After knowing in general about COVID-19, the problems are more in-depth about labor issues that arise during this pandemic, namely workers who change their routine activities to work from home or currently known as Work From Home (hereinafter referred to as WFH). WFH cannot necessarily be implemented, such as by manufacturing workers, outsourcing, apprentices and casual daily laborers, because they are paid according to the target unit yield or arrival. ${ }^{5}$ The condition of WFH in the midst of the corona outbreak can be related to the provisions of "Article 86 Paragraph letter a of Law Number 13 of 2013 concerning Manpower where every worker / laborer has the right to obtain protection for occupational safety and health." The saddest impact due to this pandemic is the massive layoffs (hereinafter referred to as layoffs) that have occurred in almost all countries affected by COVID19.

For this reason, there are special rules regarding workers who are dismissed, which are regulated in the Minister of Manpower Circular No: SE-05/M/BW/1998

\footnotetext{
${ }^{4}$ Yelvi. L, Aldo. DP, \& Siska W. (2021). "Coronavirus Disease 2019 (COVID-19): Patogenesis, Manifestasi Klinis Dan Pilihan Terapi". Jurnal Kedokteran Dan Kesehatan, 17 (1): 44-57. doi: https://doi.org/10.24853/ikk.17.1.44-57.

${ }^{5}$ Bernadetha. (ed. June 3, 2020). "Ketentuan Pelaksanaan Work From Home Di Tengah Wabah CovID19". Retrieved from hukumonline.com . accessed July 14, 2021.
} 
concerning Wages for Workers who are sent home not in the direction of termination of employment, in which the circular regulates:

a. Employers continue to pay wages in full, namely in the form of basic wages and fixed allowances as long as workers are dismissed, unless otherwise stipulated in the Work Agreement, Company Regulations or Collective Bargaining Agreement;

b. If the employer will not pay the workers 'wages in full, it is necessary to negotiate with the workers' union and / or workers about the amount of wages during the time they are sent home.

Workers/ laborers who have been dismissed due to a public health emergency due to the COVID-19 virus pandemic are still entitled to full wages or wage deductions if it has been agreed by the company and workers. On March 17, 2020, a Circular of the Minister of Manpower Number M/3/HK.04/III/2020 of 2020 concerning Protection of Workers/ Laborers and Business Continuity in the Context of Prevention and Overcoming COVID-19 (hereinafter referred to as SE Menaker 3 of 2020). SE Menaker $3 / 2020$ was issued in connection with the increasing spread of COVID-19 in several regions of Indonesia and took into account the official statement of the World Health Organization (hereinafter referred to as WHO) which declared COVID-19 a global pandemic. One of the things regulated in SE is the implementation of:

a. Menaker 3/2020For workers/ laborers who are categorized as People Under Monitoring (ODP) for COVID-19 based on a doctor's statement so that they cannot come to work for a maximum of 14 days or according to Ministry of Health standards, then wages are paid in full;

b. For workers/ laborers who are categorized as suspected cases of COVID-19 and quarantined/ isolated according to a doctor's statement, their wages are paid in full during the quarantine / isolation period;

c. For workers/ laborers who do not come to work due to being sick with COVID19 and proven by a doctor's statement, their wages are paid according to statutory regulations;

d. For companies that limit their business activities as a result of government policies in their respective regions for the prevention and control of COVID-19, 
causing some or all of their workers/ laborers not to come to work, taking into account business continuity, changes in the amount and method of payment of workers/ laborers' wages are made. according to the agreement between the entrepreneur and the worker/ laborer.

The rapid development of society in modern times due to the development of science and technology (science and technology), needs to be followed by policies in the field of law as a means to discipline and protect society in achieving its welfare. G.P. Hoefnagels states that criminal policy is part of a broader policy of social policy. ${ }^{6}$ Thus, criminal policy is a sub-system of law enforcement system and the law enforcement system itself is part of social policy. Criminal law policy focuses more on efforts to reform the law, especially material criminal law. So by considering the continuity of the business, changes in the amount and method of payment of workers' wages are carried out in accordance with the agreement between the entrepreneur and the worker. ${ }^{7}$

Criminal law policy is essentially an effort to realize criminal laws and regulations to suit the circumstances at a certain time (ius constitutum) and in the future (ius constituendum). The logical consequence is that criminal law policy is synonymous with "reforming criminal law legislation", but actually the definition of criminal law policy is in a narrow sense. It can be explained that, criminal law as a system law which consists of culture (culture), structure (structural), and substance (substantive) law. Because the law is part of the legal substance, the renewal of criminal law, in addition to updating the legislation, also includes the renewal of basic ideas and knowledge of criminal law. ${ }^{8}$

\footnotetext{
${ }^{6}$ H. Dey Ravena,Kristian. (2017). Criminal Policy. Jakarta: Prenada Media Group. p. 2-3.

${ }^{7}$ Surat Edaran Menteri Ketenagakerjaan Nomor M/3/HK.04/III/2020 TAHUN 2020 tentang Pelindungan Pekerja/Buruh Dan Kelangsungan Usaha Dalam Rangka Pencegahan Dan Penanggulangan COVID-19.

${ }^{8}$ Lilik, Mulyadi. (2008). Bunga Rapai Hukum Pidana Perspektif Teoritis Dan Praktik. Bandung: PT Alumni. p. 390.
} 


\section{Problem Statement}

Based on the description in the background, the researcher wants to discuss some of the problems that arise due to the COVID-19 pandemic, including whether the company has fulfilled the workers rights during the COVID-19 pandemic and what if many companies do not fulfill the workers' rights in the COVID-19 pandemic.

\section{Method/ Approach}

To answer legal problems in this study, a legal research was conducted.. The research method used in this research is normative juridical research method. ${ }^{9}$ The approach used is the Statute Approach, Conceptual Approach, and Case Approach. To obtain research results that can be accounted for scientifically, the authors use the theory of legal protection and the theory of criminal liability.

The research begins by first assessing and analyzing what is meant by COVID-19 so that WHO calls it a pandemic. Furthermore, an analysis is carried out on whether or not the workers' rights are fulfilled by the company. Then this research is continued by analyzing the form of corporate responsibility that does not provide the rights of workers as referred to by law and several related regulations. In analyzing the problem, the researcher used a case approach, related to the size of the company that had fulfilled the rights of workers during the COVID-19 pandemic compared to those that had not fulfilled it, then analyzed it with a statutory approach and strengthened by the existence of a conceptual approach which included doctrine. from several legal experts.

\section{Results and Discussion}

As a rule of law, Indonesia guarantees respect, protection and fulfillment of human rights (HAM). The state has an obligation (duty bearer) in ensuring welfare for the survival of every citizen of its country. One of these obligations is manifested in the form of guaranteeing the right to work and a decent living to every citizen, which is

\footnotetext{
${ }^{9}$ Peter, Mahmud Marzuki. (2013). Penelitian Hukum. Edisi Revisi. Jakarta: Kencana Prenada Media. p. 83.
} 
also a right inherent in every individual in society. ${ }^{10}$ This provision has been regulated in the 1945 Constitution of the Republic of Indonesia (hereinafter referred to as UUD NRI 1945), Law Number 39 of 1999 concerning Human Rights (hereinafter referred to as the Human Rights Law), Law Number 13 of 2003 concerning Manpower (hereinafter referred to as the Manpower Act) and Law Number 11 of 2005 concerning the International Covenant on Economic, Social and Cultural Rights.

Health is one of the basic human needs, whose rights have recently been guaranteed constitutionally. The Constitution World Health Organization 1948 (WHO) has also emphasized that "obtaining the highest degree of health is a human right for everyone" (the enjoyment of the highest attainable standard of health is one of the fundamental rights of every human being). Article $28 \mathrm{H}$ paragraph (1) states, that: "Everyone has the right to live in physical and spiritual prosperity, to have a place to live, and to have a good and healthy living environment and the right to obtain health services." The inclusion of these provisions into the 1945 Constitution of the Republic of Indonesia illustrates an extraordinary paradigm shift. Health is seen no longer just a personal matter related to luck or the grace of God that has nothing to do with the responsibilities of the state, but rather a legal right which must be guaranteed by the state. The right to health is fundamental in human rights on the human side of human dignity, the State must be a good place with equality and respect by those in health care and protection. Meanwhile, the economic right will also be for the efforts of human dignity while without any ability in the economic field, people will not be able to live and be side by side with other human beings. From this view can, efforts to the right to health and the right to the economy what became unity become the responsibility of the state and society at the same time. ${ }^{11}$

\footnotetext{
${ }^{10}$ Lembaga Bantuan Hukum Makassar. (ed. April 20, 2020). "Negara Harus Memastikan Perlindungan Dan Pemenuhan Hak-Hak Buruh Selama Masa Pandemi Covid-19". Retrieved from lbhmakassar.org. accessed July 13, 2021.

${ }^{11}$ Mei, Susanto \& Teguh Tresna PA. (2020). "EKONOMI VERSUS HAK ASASI MANUSIA DALAM PENANGANAN COVID-19: DIKOTOMI ATAU HARMONISASI (The Economy versus Human Rights In Handling Covid-19: Dichotomy or Harmonization)". Jurnal HAM, 11 (2): 301-317. doi. $\underline{10.30641 / h a m .2020 .11 .301-317}$
} 
Barriers to fulfilling the right to high health standards have occurred in various COVID-19 referral hospitals which have a number of problems such as minimal access to information, shortages of medical personnel, lack of facilities and infrastructure to support health services, and there are no special procedures for patients who want to do tests COVID-19. ${ }^{12}$ The minimal preparation and handling of the state has resulted in uncontrolled numbers of the spread, transmission and handling of COVID-19 in the community. A number of cases that endanger health and violations of human rights that result from not fulfilling the right to information include procedures for the use of disinfectants, use of drugs and supplements that are not recommended, violations of privacy to discriminatory practices such as refusing to bury a corpse exposed to COVID-19.

The global pandemic COVID-19 cannot and cannot be an excuse for every country to make policies that are repressive and violate human rights. Instead, this should be an evaluation to re-see the COVID-19 incident as a public health issue that has an impact on social welfare issues. Moreover, in issuing policies, the state must think long-term about the long-term impact on civil liberties in society after the pandemic is over because the real threat is the virus, not citizens.

In dealing with the COVID-19 pandemic, it is not only done by the government. The role of the community to maintain distance and stay at home is a determinant of success in ending COVID-19 in Indonesia. So that the PSBB status is expected to reduce the number of positive COVID-19. The role of the company in this case is to enforce the WFH, namely working from home. The WFH work system has high flexibility. This is to support employee balance between work and life. This is to reduce the risk of corona virus transmission and the safety of workers/ laborers. However, not all WFH workers/ laborers, even many workers/ laborers have experienced layoffs. Because of the establishment of Presidential Decree No. 12 of 2020, the Company relented in its position in the Working Relationship, by means of severance money, work time money, and money at any time which rights should be.

\footnotetext{
12 Kontras. (ed. May 11, 2020). "Wabah COVID-19 Bukan Alasan Untuk Mengorbankan HAM Dan Demokrasi". Retrieved from kontras.org. accessed July 12, 2021.
} 
In this Working Relationship article which article can which Article 164 paragraph (3) of the Labor Law with efficiency reasons. ${ }^{13}$

One of the characteristics of labor law is the existence of a source of law from the parties, namely work agreements, collective labor agreements and company regulations. Work agreements, collective labor agreements and company regulations can also be considered as the legal basis for the working relationship between workers / laborers and entrepreneurs. After the enactment of the Manpower Act, this is known as industrial relations. Thus, the work relationship basically includes matters concerning:

1. Making a work agreement (a starting point for the existence of an employment relationship);

2. Worker's obligations (i.e. doing work);

3. Obligations of entrepreneurs;

4. Termination of employment relationship;

5. How to resolve disputes between the parties concerned.

Article 1 point 14 of the Manpower Act, it states that a work agreement is an agreement between a worker / laborer and an entrepreneur or employer that contains the conditions of work, rights and obligations of the parties. " It is clear that the relationship between workers and companies must then be considered regarding the things that are done in order to fulfill workers' rights in the COVID-19 pandemic. The state must ensure that companies do not make policies that can harm workers during the COVID-19 Pandemic. If the Government is not firm, then this situation will be very dangerous for the community at large, which of course will be detrimental to the State in terms of finance to overcome the economic impact of its citizens, the situation and the potential threat of hunger to socio-political turmoil may occur if the company is allowed to make policies that are detrimental Workers.

The workers' rights seem ignored by the labor office so that the labor office during the pandemic period works without the basis of statutory regulations, even though the Manpower Office has the authority to carry out supervision, even as a civil servant investigator in the labor sector, the labor office can carry out investigative and

13 Herman., et.al. (2020). "Tinjauan Yuridis Mengenai Dampak COVID-19 Terhadap Pemutusan Hubungan Kerja". Halu Oleo Law Review, 4 (2): 157-176. doi: 10.33561/holrev.v4i2.1428. 
investigative actions against labor crimes. ${ }^{14}$ However, this authority was not exercised at all on the grounds that employers are currently losing money, while the Manpower Law stipulates that the reason for layoffs on the grounds that the company is losing money can only be done on the grounds that the company has lost two consecutive years by showing the results of the audit from an independent auditor.

To be able to analyze and answer the problems that exist, we need to know about Workers' Rights for Pandemic COVID-19 of them are:

1. Work From Home (Hereinafter referred to WFH)

WFH problem in the midst of an outbreak of COVID-19 can be attributed to the provision of "Article 86 paragraph (1) letter a of the Manpower Act, in which every worker / laborer has the right to obtain protection for occupational safety and health." Several provinces, one example is the DKI Jakarta Provincial Manpower, Transmigration and Energy Office itself has issued a Circular of the DKI Jakarta Provincial Manpower, Transmigration and Energy Office Number 14/SE/2020 of 2020 concerning the Appeal to Work at Home which follows up on the DKI Jakarta Provincial Governor's Instruction Number 16 of 2020 concerning Increased Alertness Against the Risk of Transmission of COVID-19 Infection. According to the SE Disnakertrans and Energi DKI Jakarta 14/SE/2020, company leaders are expected to be able to take preventive steps related to the risk of transmitting COVID-19 infection, by doing work at home. The preventive measures that can be taken are grouped into three categories ${ }^{15}$ :

a. The company can temporarily suspend all of its business activities.

b. The company can temporarily reduce some of its business activities (part of its employees, time and operational facilities).

c. Companies that cannot stop their business activities, given their direct interests related to health services, the need for basic necessities, and fuel oil.

\footnotetext{
${ }^{14}$ Kanyaka, Prajnaparamitha \& Mahendra RG., (2020). "Perlindungan Status Kerja Dan Pengupahan Tenaga Kerja Dalam Situasi Pandemi COVID-19 Berdasarkan Perspektif Pembaharuan Hukum". Administrative Law \& Governance Journal, 3 (2): 314-328. doi: https://doi.org/10.14710/alj.v3i2.314$\underline{328}$

$\frac{328}{15}$ Dinas Tenaga Kerja Transmigrasi \& Energi. "SURAT EDARAN KEPALA DINAS TENAGA KERJA, TRANSMIGRASI DAN ENERGI PROVINSI DKI JAKARTA Nomor 14/SE/2020 Tahun 2020 Himbauan Bekerja Di Rumah (Work From Home)".
} 
After the implementation of Large-Scale Social Restrictions (PSBB), especially in the DKI Jakarta area, the company's business activities in the PSBB area were then formally restricted. However, this provision is exempted for companies engaged in the defense and security sector, public order, food needs, fuel oil and gas, health services, economy, finance, communications, industry, export and import, distribution, logistics and other basic necessities.

So by considering the continuity of the business, changes in the amount and method of payment of workers' wages are carried out in accordance with the agreement between the entrepreneur and the worker. This is in accordance with the meaning of wages in Article 1 number 1 of Government Regulation Number 36 of 2021 concerning Wages which reads:

"Wages are workers / laborers' rights received and expressed in the form of money as compensation from employers or employers to designated workers / laborers and paid according to a work agreement, agreement, or statutory regulations, including allowances for workers / labor and their families for a job and / or service that has been or will be performed." 16

The issuance of regulations in the context of handling the spread of COVID-19 is an effort to support the existence of Law Number 24 of 2007 concerning Disaster Management which defines disease outbreaks as one of the non-natural disasters that need to be managed with potential threats. ${ }^{17}$ For these regulations, the efforts currently being carried out are:

a) Policy Social Distancing / Physical Distancing

The existence of Social Distancing has so far been very effective in preventing the spread of viruses / diseases, namely by preventing sick people from making close contact with people for prevent transmission. However, seeing the current phenomenon, in fact social distancing is still in the form of an appeal that if it is not helped to go viral on social media, there will be fewer people who will know about it. Therefore, the policy should social distancing be included in government regulations in lieu of laws regarding efforts to deal with the COVID-19 outbreak,

${ }^{16}$ Pasal 1 angka 1 Peraturan Pemerintah Republik Indonesia Nomor 36 Tahun 2021 Tentang Pengupahan.

17 Pasal 1 angka 3 Undang-Undang Republik Indonesia Nomor 24 Tahun 2007 Tentang Penanggulangan Bencana. 
one of which regulates social distancing is an obligation, if necessary there is an affirmation in the form of sanctions according to positive law, so that people are not only aware of the importance of social distancing but also applying the practice. It is deemed necessary to limit individual rights in social distancing because the condition that occurs is an emergency that threatens public health.

The term social distancing then changes to physical distancing in accordance with the term used by WHO because the use of the term social distancing seems to stop social interaction in society while what is actually wanted is to maintain physical distance. From this, various activities that were initially carried out with a close physical distance were then converted into activities that created physical distance, among others, learning online (method online), use of themechanism (WFH), closing shopping places and efforts. others that can prevent the spread of COVID-19.

b) Protection for Health Workers as

Frontline Health workers stand at the forefront in preventing an increase in the number of infections so that the government needs to guarantee protection and work safety for medical personnel in an effort to deal with COVID-19 so that working hours are regulated, increasing the number of referral hospitals, and compliance. primary needs of each health worker, provision of Personal Protective Equipment (PPE), then determining the priority scale for the provision of PPE.

c) Large- scale social restrictions

Scale Social Restrictions The authority for large-scale social restrictions based on Law Number 6 of 2018 concerning Health Quarantine is the absolute authority of the Central Government. Article 1 Number 1 states that "health quarantine is carried out to prevent and prevent the exit or entry of diseases and / or public health risk factors that have the potential to cause a public health emergency." Then for the emergency condition of the spread of COVID-19, the government then issued Government Regulation Number 21 of 2020 concerning Large-Scale Social Restrictions in the context of the Acceleration of Handling Corona Virus Disease (COVID-19). 
d) Government transparency in handling the COVID-19 pandemic.

Information disclosure about COVID-19 is a must at this time. The disclosure of information regarding COVID-19 basically refers to Law Number 14 of 2008 concerning Public Information which demands that the Government as a public agency to transparently open this case from the start.

Referring to Law No. 14 of 2008, the COVID-19 pandemic is not public information that is exempted by law, as information that could endanger the state, because in fact the information on the pandemic has been known to the general public since the first day of the outbreak in Wuhan, China, and has been informed by the world health agency, WHO. Furthermore, there are provisions that oblige the Government and Regional Governments outside of Law Number 14 Year 2008 to provide information as clearly as possible and open access for the public to find out information about health or infectious diseases, namely Article 17, Article 154 and 155 of Law Number 36 of 2009. In addition, Article 79 and Article 80 of Law Number 6 of 2018 concerning Health Quarantine provide a basis for authority for the central and local governments to convey information on health quarantine as part of the prevention and eradication of public health risks that can cause emergency.

Based on the conditions above, it can be said that from a legal aspect, various regulations have been issued to prevent the spread of COVID-19 but the reality so far shows that there has been no significant change in the handling of COVID-19 cases in Indonesia, the number of patients is increasing, the death rate is also increasing. The existence of existing regulations will not be effective if they are not supported by firmer but polite efforts in society. The existence and extra attention of all related parties is very urgent to provide understanding to the public regarding the spread of this virus. So that many workers find it difficult and this creates a new problem. Unemployed can seek settlement of industrial relations disputes, according to the procedures in the prevailing laws and regulations. 
Legal Due To Companies That Do Not Meet Workers Rights In The Covid-19 Pandemic Period

Workers / laborers' rights during the COVID-19 pandemic include the fulfillment of workers' wages, the Wage Protection Convention, 1949 (Number 95) states that wages must be paid regularly. Upon termination of the employment contract, the final settlement of all wages due will apply as determined, or if not determined, within a reasonable timeframe. In the event of bankruptcy or legal liquidation of a business (including the result of the impact of COVID-19), the Wages Protection Convention, 1949 (Number 95) states that employed workers will be treated as creditors with special privileges for unpaid wages protected by applicable national laws.

Meanwhile, regarding the wages of workers / laborers who are temporarily laid off due to the COVID-19 outbreak, stick to the Circular of the Minister of Manpower Number M / 3 / HK.04 / III / 2020 of 2020 concerning Protection of Workers / Laborers and Business Continuity in the Context of Preventing and Overcoming COVID-19. (SE Menaker M / 3 / HK.04 / III / 2020). Wage protection for employees who are temporarily laid off due to the COVID-19 outbreak is regulated with the following conditions: ${ }^{18}$

a. Implementing wage protection for workers / laborers related to the COVID-19 pandemic;

b. For workers / laborers who are categorized as People Under Monitoring (ODP) for COVID-19 based on a doctor's statement so that they cannot come to work for a maximum of 14 days or according to Ministry of Health standards, their wages are paid in full;

c. For workers / laborers who are categorized as suspected cases of COVID19 and quarantined / isolated according to a doctor's statement, their wages are paid in full during the quarantine / isolation period;

d. For workers / laborers who do not come to work due to being sick with COVID-19 and proven by a doctor's statement, their wages are paid according to statutory regulations;

e. For companies that limit their business activities as a result of government policies in their respective regions for the prevention and control of COVID-19, causing some or all of their workers / laborers not to come to work, taking into account business continuity, changes in the amount and method of payment of workers / laborers' wages are made. according to the agreement between the entrepreneur and the worker / laborer.

\footnotetext{
${ }^{18}$ Surat Edaran Menteri Ketenagakerjaan Nomor M/3/HK.04/III/2020 TAHUN 2020 tentang Pelindungan Pekerja/Buruh Dan Kelangsungan Usaha Dalam Rangka Pencegahan Dan Penanggulangan COVID-19.
} 
Wages for workers / laborers who were temporarily laid off due to the COVID19 outbreak, taking into account the continuity of the business, changes in the amount and method of payment of wages are carried out according to the agreement between the entrepreneur and the worker / laborer, so that the change is not carried out unilaterally by the entrepreneur. For example, based on this circular, employers can reduce the amount of wages that must be paid to workers / laborers so that they have enough capital to continue their business in the midst of the COVID-19 outbreak as long as it is based on an agreement between the employer and the employee.

If employers do not carry out the above provisions and change the amount and method of paying wages unilaterally, this has the potential to lead to industrial relations disputes, namely rights disputes that must be resolved in accordance with the mechanism of Law Number 2 of 2004 concerning Settlement of Industrial Relations Disputes. Meanwhile, regarding the reasons for legal deduction of wages, it is necessary to first understand the definition of wages according to Article 1 number 30 of the Manpower Act, which are:

Wages are the rights of workers / laborers that are received and expressed in the form of money as compensation from employers or employers to workers / laborers who determined and paid according to a work agreement, agreement, or statutory regulations, including allowances for workers / laborers and their families for a job and / or service that has been or will be performed.

Furthermore, the wage component according to Article 5 paragraph (1) Government Regulation Number 78 of 2015 concerning Wages consists of: (a) Wages without allowances; (b) Basic wages and fixed allowances; or (c) Basic wages, fixed allowances and non-permanent allowances. As for the deduction of wages by employers carried out in accordance with the work agreement, company regulations, or collective labor regulations for: (a) fines; (b) compensation; and / or (c) advance wages. In addition, there are wage deductions by employers for third parties that can only be done if there is a power of attorney from the worker / laborer which can be withdrawn at any time. 


\section{Discussion}

Cutting wages of employees due to the company losing money as a result of an outbreak of COVID-19 is not based on law and can give rise to industrial disputes, ie disputes over rights. In addition, if the employer is unable to pay the wage according to the minimum wage, it will be more appropriate for the company to postpone the payment of wages as permitted in Article 90 paragraph (2) of the Manpower Law which states that employers who are unable to pay the minimum wage can be postponed. .The procedure for deferring minimum wages is then regulated in the Decree of the Minister of Manpower and Transmigration Number KEP-231 / MEN / 2003 of 2003 concerning Procedures for Postponing the Implementation of Minimum Wages (Kep menakertrans 231/2003). What should be noted is that entrepreneurs who are unable to pay the minimum wage can apply for a postponement of the minimum wage to the governor through the provincial agency responsible for manpower affairs no later than 10 days before the date the minimum wage comes into effect. The application is the result of a written agreement between the entrepreneur and the registered worker / laborer or trade / labor union.

Due to the COVID-19 outbreak and has not been able to pay its workers' wages according to the minimum wage, the company can postpone wage payments by first conducting negotiations with workers / laborers or trade / labor unions regarding the suspension. However, the postponement of the payment of minimum wages by employers to workers / laborers does not automatically eliminate the obligation of employers to pay the difference in minimum wages during the suspension period.

The imposition of fines does not eliminate the obligation of employers to continue to pay wages to workers / laborers. Wages are an important and basic component in industrial relations, so the Manpower Law and Government Regulation Number 78 of 2015 concerning Wages provide protection for wages. Efforts that can be made if wages are not paid are to take the route or methods as regulated in Law Number 2 of 2004 concerning Settlement of Industrial Relations Disputes. 
The paths that can be taken based on the provisions of the Law on the Settlement of Industrial Relations Disputes in an effort to resolve disputes regarding the right to wages include:

1. Bipartite Path

A negotiation between workers and employers to resolve industrial relations disputes, which are disputes over rights between workers and employers. Dispute resolution through bipartite must be resolved within 30 days. ${ }^{19}$ If a settlement agreement is reached in bipartite negotiations, a Collective Agreement is made signed by the parties. If the bipartite negotiation fails or the employer refuses to negotiate, then the settlement will then be pursued through the tripartite route, namely by registering with the sub-office or the Manpower and Transmigration Office in the regency or municipality of the area where you work. ${ }^{20}$

2. Industrial Relations Mediation Path

A settlement of disputes between workers and employers, mediated by a mediator from the Manpower and Transmigration Office. For disputes over rights, what can be done is to mediate. Industrial Relations Mediation is the settlement of disputes over rights, disputes over interests, disputes over termination of employment, and disputes between trade unions / labor unions within one company only through deliberation mediated by one or more neutral mediators. ${ }^{21}$ If the mediation is successful, then the result of the agreement is stated in a Collective Agreement signed by the parties and witnessed by the mediator and registered at the Industrial Relations Court at the District Court in the jurisdiction of the parties that entered into the Collective Agreement to obtain a proof of registration deed. If there is no common ground, the Mediator shall write down the results of the negotiations in a written recommendation and if one of the parties rejects the recommendation, then one of the parties can file a dispute over the Industrial Relations Court.

3. Industrial Relations Conciliation

Is the settlement of disputes of interest, disputes over termination of employment or disputes between trade unions/labor unions in only one company through deliberation mediated by one or more neutral conciliators.

4. Industrial Relations Arbitration

Is the settlement of a dispute of interest, and a dispute between trade unions/labor unions in only one company, outside the Industrial Relations Court through a written agreement from the disputing parties to submit dispute resolution to an arbitrator whose decision is binding on the parties and is final.

\footnotetext{
19 Pasal 3 ayat 2 Undang-Undang Republik Indonesia Nomor 2 Tahun 2004 Tentang Penyelesaian Perselisihan Hubungan Industrial.

${ }^{20}$ Pasal 4 ayat 1 Undang-Undang Republik Indonesia Nomor 2 Tahun 2004 Tentang Penyelesaian Perselisihan Hubungan Industrial.

${ }^{21}$ Pasal 1 angka 11 Undang-Undang Republik Indonesia Nomor 2 Tahun 2004 Tentang Penyelesaian Perselisihan Hubungan Industrial.
} 


\section{Industrial Relations Court}

Is a special court formed within the district court authorized to examine, hear and give decisions against industrial relations disputes.

Every industrial relations dispute must be resolved first through deliberative bipartite negotiations to reach a consensus which must be resolved within 30 working days from the date the negotiations began. If within 30 days, one of the parties refuses to negotiate or has conducted negotiations but does not reach an agreement, then the bipartite negotiation is deemed a failure. In the event that the bipartite negotiations fail, then one or both parties shall register the dispute with the local manpower agency responsible for attaching evidence that the bipartite negotiations have taken place. The disputes over rights that have been recorded must then be resolved through mediation before being submitted to the industrial relations court. If the mediation does not reach an agreement as stated in the collective agreement, then one of the parties can file a lawsuit at the industrial relations court. Parallel to the provision of incentive packages for employers and workers, in this difficult situation the government must also be the party capable of mediating the dialogue between employers and workers and trade unions to prevent layoffs. The role of the government can be pursued as a mediator to find solutions agreed upon by both parties, especially regarding the fulfillment of workers' rights, if layoffs are unavoidable. In this case, the government can form a Task Force for Handling Layoffs so that a better response to the problems of employers and workers during this pandemic can be anticipated and resolved early on.

\section{Conclusion}

Policies must be implemented to protect workers / laborers' rights during the COVID19 pandemic, so that the Government and Employers must respond to any changes that occur due to the COVID-19 pandemic on the work system of workers / laborers. These changes include the application of a work from home system, social distancing, and restrictions on public transportation, which are currently being implemented by several local governments. The government, in this case the Ministry of Manpower must be active in providing policy information for work and conducting regular policy reviews. Policies that can be implemented include the policy of reducing working 
days and hours, dismissing workers / laying off workers, and so on. In addition, the government also needs to carry out an employment mitigation plan in the face of a worsening work situation due to the economic crisis as a result of the COVID-19 pandemic. This can be done by implementing government programs that can absorb a large workforce and skills development support programs such as those that have been implemented, namely the provision of pre-employment cards and the provision of direct cash assistance (BLT). The government has issued incentive packages for entrepreneurs such as exemption or reduction in tax payments and budget grants for the small business sector. The government itself plans to provide a stimulus of Rp. 2 trillion to increase the purchasing power of cooperatives and Micro, Small and Medium Enterprises (MSMEs). In addition, social incentives are also provided by the government for workers who are laid off or unable to work, such as non-formal sector workers. This incentive is in the form of direct assistance and fee discounts for facilities provided by the government (electricity and water). This policy needs to ensure realization and monitor so that it is right on target.

Employers and workers together with trade unions need to carry out a transparent dialogue from an early age in anticipating labor conditions due to the COVID-19 pandemic. Companies that because of their industrial nature require the presence of workers must regulate work systems by prioritizing occupational safety and health. It is necessary to discuss the anticipation of the worst conditions of work relations among them, such as efficiency, working hours arrangements and the division of labor. This dialogue is the main door to build a common understanding in facing the impact of the COVID-19 pandemic for both.

\section{References}

Bernadetha. (ed. June 3, 2020). "Ketentuan Pelaksanaan Work From Home Di Tengah

Wabah COVID-19". Retrieved from hukumonline.com . accessed July 14, 2021.

Dinas Tenaga Kerja Transmigrasi \& Energi. "SURAT EDARAN KEPALA DINAS TENAGA

KERJA, TRANSMIGRASI DAN ENERGI PROVINSI DKI JAKARTA Nomor 14/SE/2020 Tahun 2020 Himbauan Bekerja Di Rumah (Work From Home)".

Herman., et.al. (2020). "Tinjauan Yuridis Mengenai Dampak COVID-19 Terhadap

Pemutusan Hubungan Kerja". Halu Oleo Law Review, 4 (2): 157-176. doi: 10.33561/holrev.v4i2.1428. 
Kontras. (ed. May 11, 2020). "Wabah COVID-19 Bukan Alasan Untuk Mengorbankan HAM Dan Demokrasi". Retrieved from kontras.org. accessed July 12, 2021.

Lembaga Bantuan Hukum Makassar. (ed. April 20, 2020). "Negara Harus Memastikan Perlindungan Dan Pemenuhan Hak-Hak Buruh Selama Masa Pandemi Covid-19". Retrieved from lbhmakassar.org. accessed July 13, 2021.

Levani, Y., Prasetya, AD., \& Mawaddatunnadilla, S. (2021). "Coronavirus Disease 2019 (COVID-19): Patogenesis, Manifestasi Klinis Dan Pilihan Terapi". Jurnal Kedokteran Dan Kesehatan, 17 (1): 44-57. doi: https://doi.org/10.24853/jkk.17.1.44-57.

Marzuki, Peter M. (2013). Penelitian Hukum. Edisi Revisi. Jakarta: Kencana Prenada Media.

Mulyadi, Lilik. (2008). Bunga Rapai Hukum Pidana Perspektif Teoritis Dan Praktik. Bandung: PT Alumni.

Peraturan Pemerintah Republik Indonesia Nomor 36 Tahun 2021 Tentang Pengupahan. 2 Februari 2021. LEMBARAN NEGARA REPUBLIK INDONESIA TAHUN 2021 NOMOR 46. Jakarta.

Prajnaparamitha, K. \& Mahendra RG., (2020). "Perlindungan Status Kerja Dan Pengupahan Tenaga Kerja Dalam Situasi Pandemi COVID-19 Berdasarkan Perspektif Pembaharuan Hukum". Administrative Law \& Governance Journal, 3 (2): 314-328. doi: https://doi.org/10.14710/alj.v3i2.314-328

Ravena, H. Dey,. Kristian. (2017). Criminal Policy. Jakarta: Prenada Media Group.

Surat Edaran Menteri Ketenagakerjaan Nomor M/3/HK.04/III/2020 TAHUN 2020 tentang Pelindungan Pekerja/Buruh Dan Kelangsungan Usaha Dalam Rangka Pencegahan Dan Penanggulangan COVID-19.

Susanto, Mei., \& Asmara, Teguh, TP. (2020). "EKONOMI VERSUS HAK ASASI MANUSIA DALAM PENANGANAN COVID-19: DIKOTOMI ATAU HARMONISASI (The Economy versus Human Rights In Handling Covid-19: Dichotomy or Harmonization)". Jurnal HAM, 11 (2): 301-317. doi. 10.30641/ham.2020.11.301317

Undang-Undang Republik Indonesia Nomor 2 Tahun 2004 Tentang Penyelesaian Perselisihan Hubungan Industrial. 14 Januari 2004. LEMBARAN NEGARA REPUBLIK INDONESIA TAHUN 2004 NOMOR 6. Jakarta.

Undang-Undang Republik Indonesia Nomor 24 Tahun 2007 Tentang Penanggulangan Bencana. 26 April 2007. LEMBARAN NEGARA REPUBLIK INDONESIA TAHUN 2007 NOMOR 66. Jakarta. 